\title{
Why is the Number of Patients of Methadone Maintenance Therapy in Indonesia Stagnant? Improvement of Service
}

\section{Wini Wulansari and Martya Rahmaniati Makful}

Faculty of Public Health, Universitas Indonesia, Depok, Indonesia

\section{Abstract}

At first, Methadone Maintenance Therapy Program (MMTP) was created to handle the increasing problem of HIV caused by used drug through injection. The spread of HIV through the needle is so fast that requires a comprehensive therapy effort. In 2003, Indonesia made a project pilot at drug dependence hospital in Jakarta and public hospital in Bali. The results of the project had positive impacts. There was behavior changing to stop using drugs. MMTP was firstly launched in 2006. The program used methadone dosage of liquid by drinking. The implementation of MMTP in Indonesia

Corresponding Author: Wini Wulansari

winiws1744@gmail.com

Received: 26 December 2018 Accepted: 23 February 2019 Published: 7 March 2019

Publishing services provided by Knowledge E

(c) Wini Wulansari and Martya Rahmaniati Makful. This article is distributed under the terms of the Creative Commons

Attribution License, which permits unrestricted use and redistribution provided that the original author and source are credited.

Selection and Peer-review under the responsibility of the $2 \mathrm{nd}$ International Meeting of Public Health 2016 Conference Committee.

\section{G OPEN ACCESS} wasn't maximized. Based on data from the Ministry of Health in 2015, the number of active patients was 2,300 and in 2013 , there was 2,457 . There was a decrease in the number of patients in the two years amounted to $6.38 \%$. The research method used quality research by literature review and an in-depth interview with IDUs. The subjects of study had improvements of methadone services and evaluation of the therapeutic program implementation. The results of the research had a non-compliance with service guidelines, lack of psychosocial services, the performance of officers not optimal, and there were external influences on the adherence of patients - the conclusion needed capacity building, the involvement of stakeholders in this program, monitoring client through task shifting of an officer.

Keywords: Methadone; drugs; HIV; IDU

\section{Introduction}

At first, MMTP was created to handle the increasing problem of HIV that caused by used drug through injection. The spread of HIV through a needle is so fast that requires a comprehensive therapy effort. In 2011, Indonesia Biological and Behavior Survey showed about $50 \%$ of IDUs have not followed of harm reduction program ( $\mathrm{MoH}$ Republic of Indonesia 2011).

HIV prevalence in IDUs group base on IBBS in 2009 and 2013 had increased, $27 \%$ and 39.5\% (MoH Republic of Indonesia 2013). 


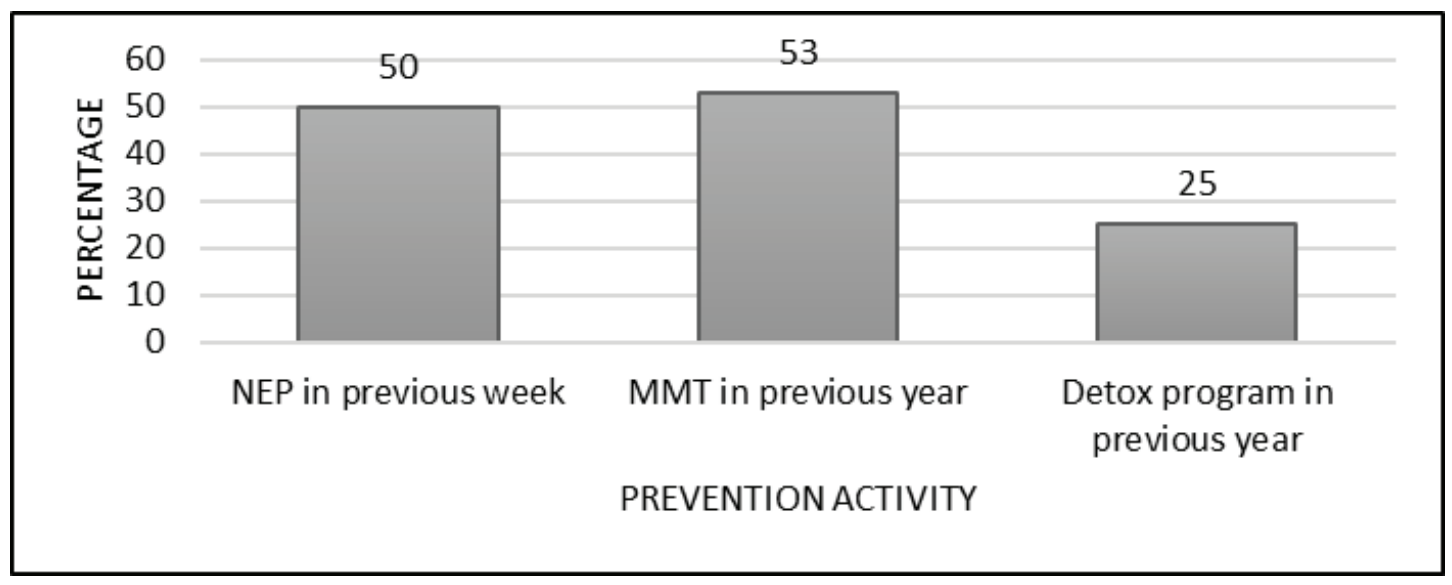

Figure 1: Distribution of IDUs That Followed the Harm Reduction Program.

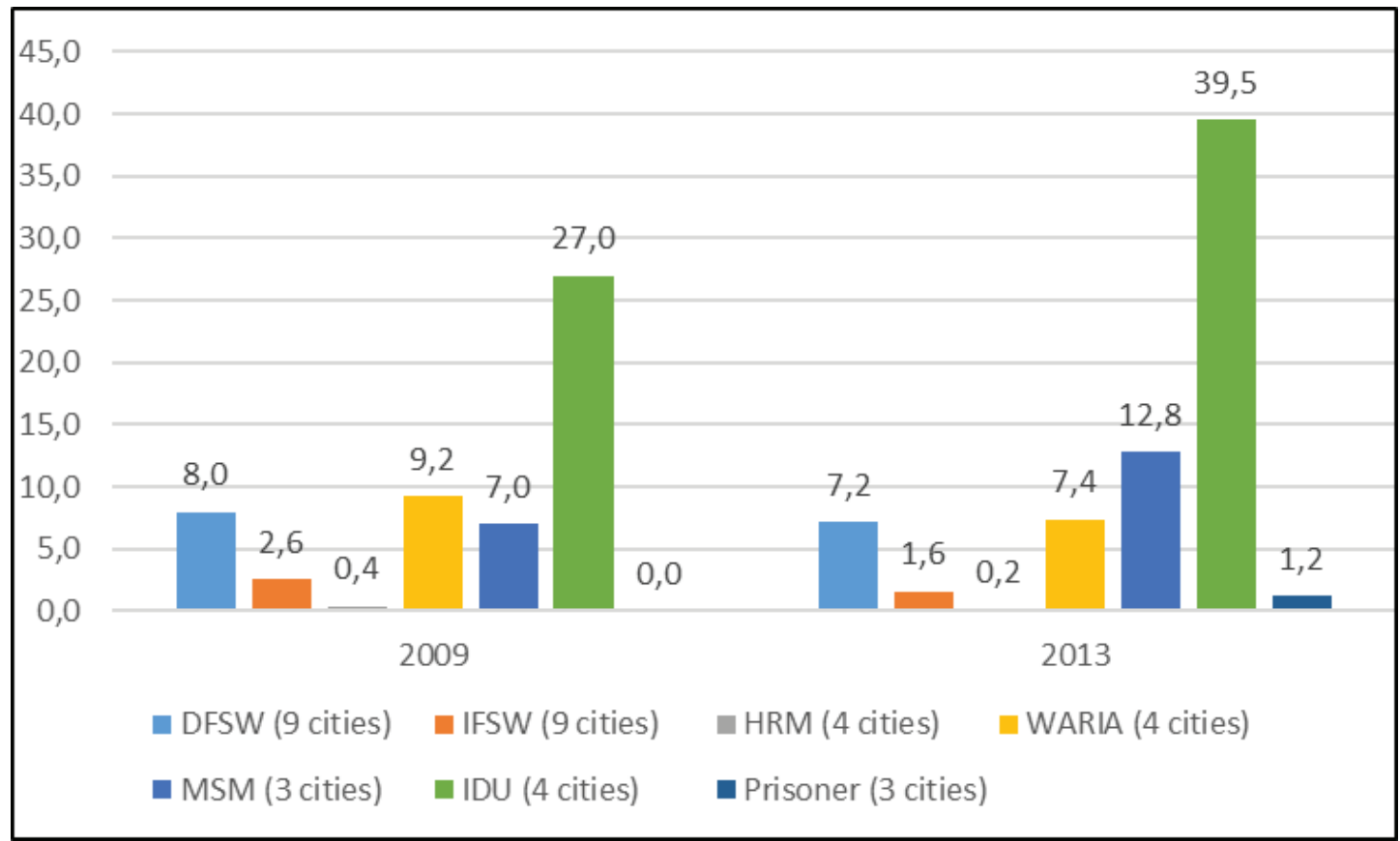

Figure 2: HIV Prevalence Base on Risk Population. (Source: MoH Republic of Indonesia (013).)

The behavior of sharing needles of IDU in 2009 and 2013 had decreased by 35\% and $27 \%$.

Whereas behavior of sharing needles of IDU in injecting previous week in 2009 and 2013 had increased, 21\% and 34\% (MoH Republic of Indonesia 2013).

In 2003, Indonesia had collaborated with WHO to effort of harm reduction program that it made a pilot project in 2 health facilities at drug dependence hospital in Jakarta and public hospital in Bali. The result of the project had impacted positively. There were changes in the behavior of IDU to stop using drugs. First methadone maintenance therapy (MMT) was launch in 2006, in line with enactment minister of health decree about 


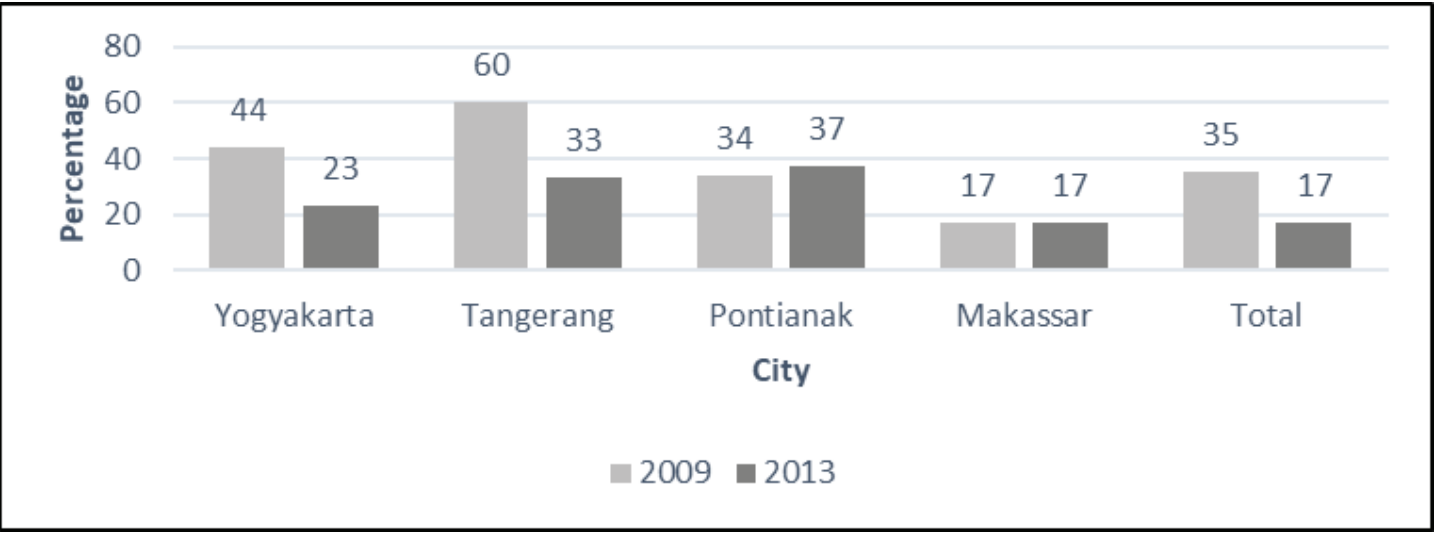

Figure 3: The Behavior of Sharing The Needles of Idus in Last Injecting at Four Cities in Indonesia.

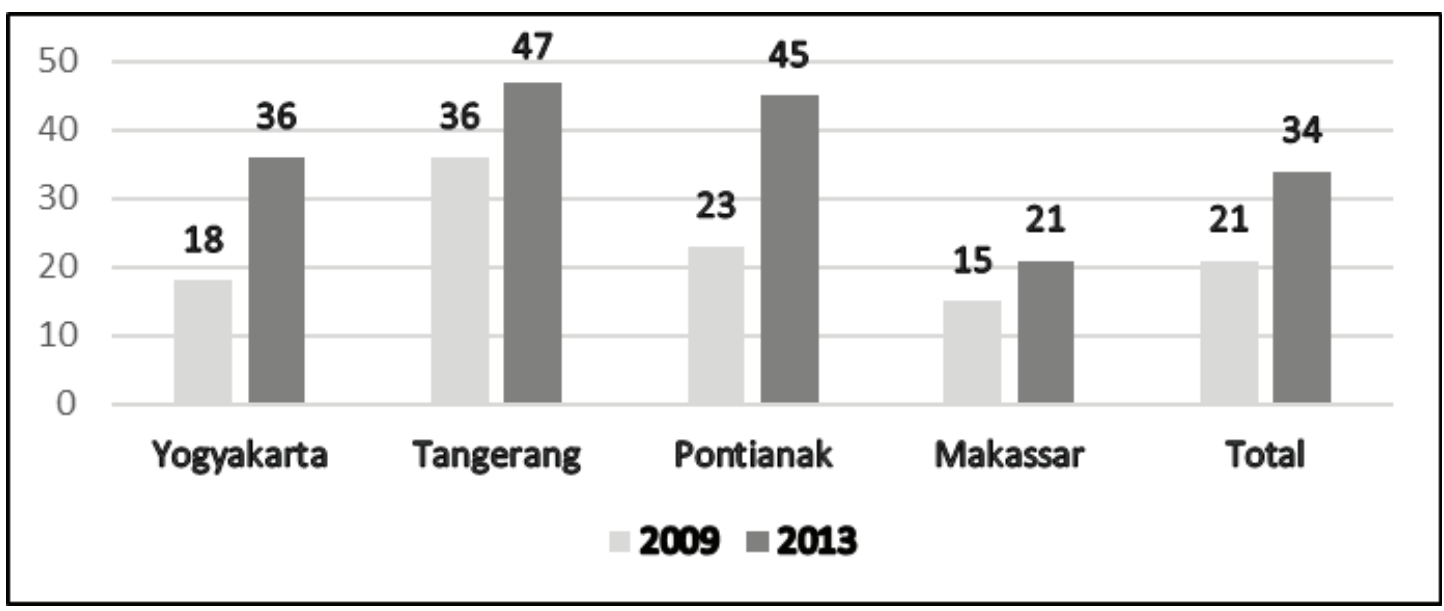

Figure 4: The Behavior of Sharing Needles in Injecting Previous Week.

Hospital and Trial Service of Satellite and methadone maintenance therapy Program. This program used substitution in the preparation of liquid methadone by a drink.

The implementation of MMTP in Indonesiawas perceived not maximal. Based on $\mathrm{MoH}$ Republic of Indonesia data in 2015, the number of active patient in MMT was 2.300 people, and the name of the active patient was 2.529 people in 2013 (see Fig. 5) and the number of health facilities that undertaken MMT as many as 92 units (see Fig. 6). This means there was a decrease in patient number in 2 years as many as $9.05 \%$. Otherwise, the number of MMT had increase six units. Therefore, it needs to follow up to improve the quality of the MMT service (MoH Republic of Indonesia 2015).

Now, Indonesia has 92 units of MMT that spread over 18 provinces consist of 44 community health centers, 29 public hospitals, nine psychiatry hospitals, six correction institutions, and four prisons. 


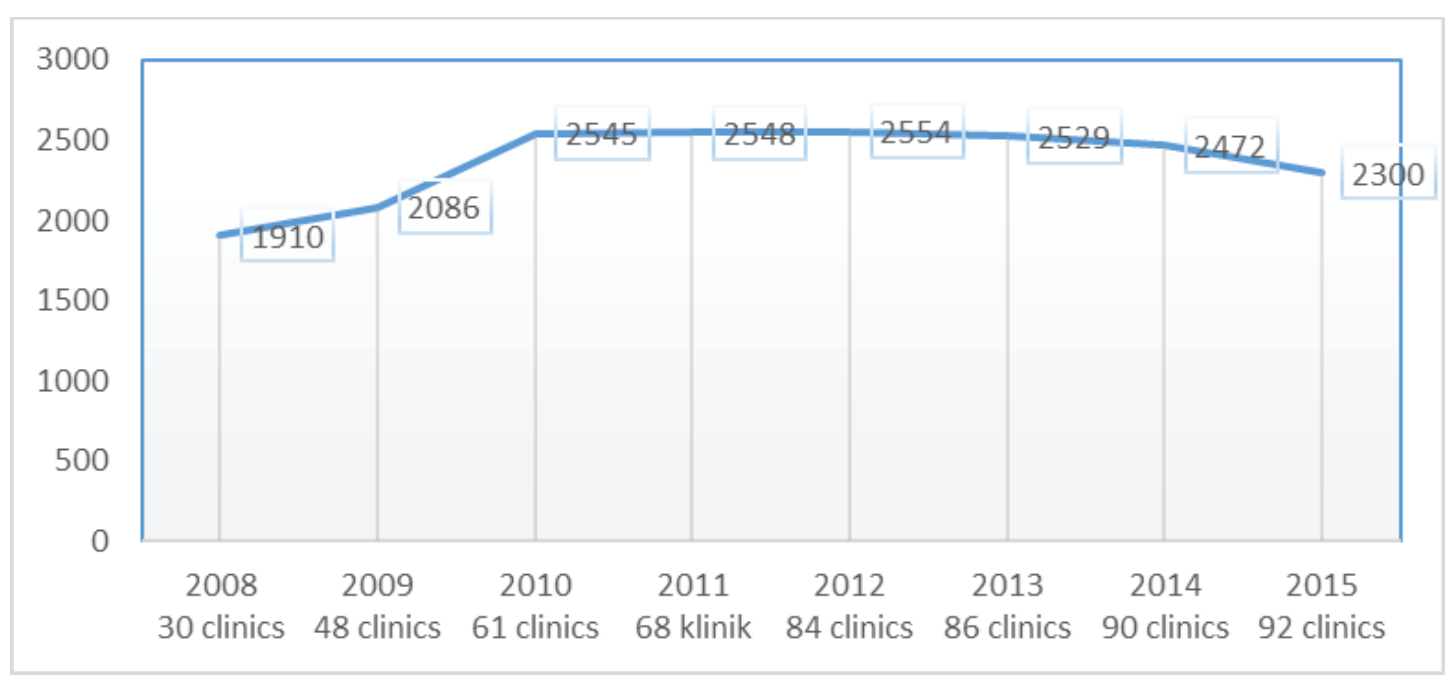

Figure 5: Graphic of the Number of Active Patients in MMT Every Year.

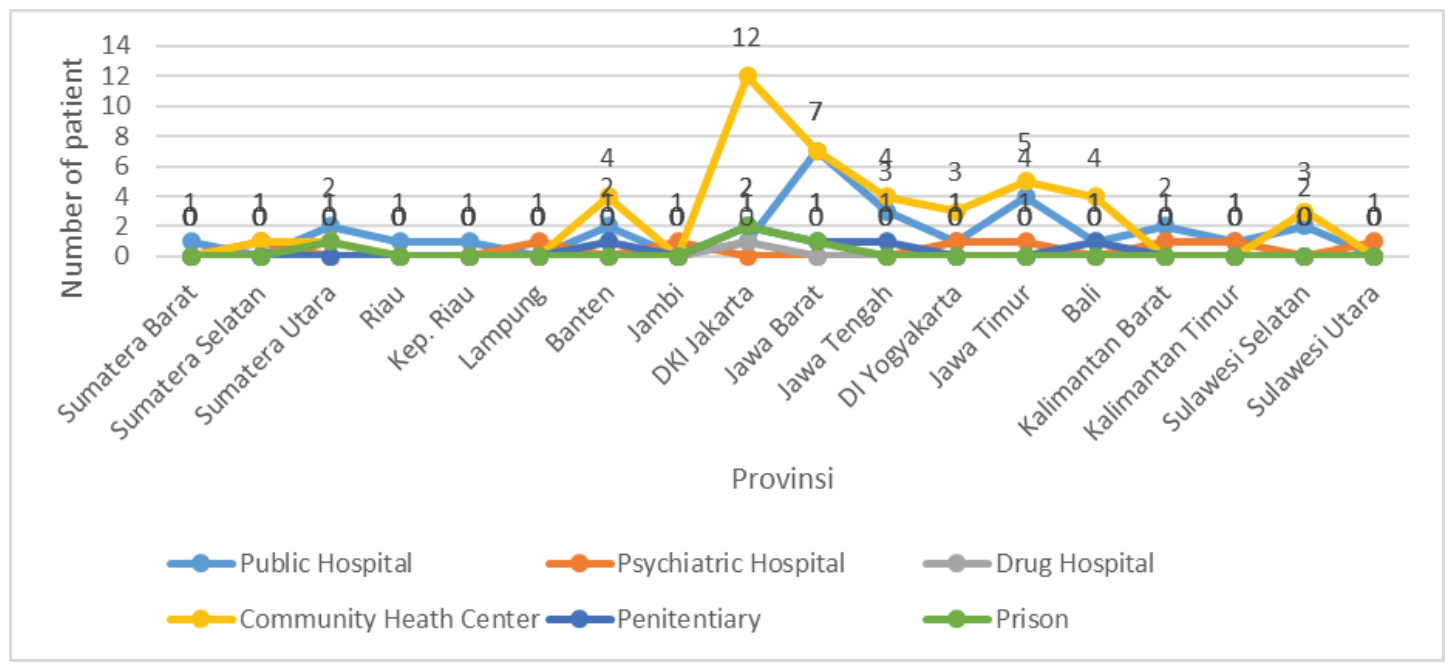

Figure 6: Graphic of Distribution of Health Facilities in MMT.

\section{Methods}

The research used qualitative study with collecting data technique by literature study and interview with IDUs from Yayasan Karisma, East Jakarta. A literature study was related to collecting some reference related problems and government policies. Interview with IDUs was done by department interviews to gather informations.

\section{Results}

Base on literature study and interviews with IDUs, there was found some problems, as follows: 


\subsection{Incompatibility of implementation procedures handbook}

Both health care workers and patients were less consistent in carrying out procedures appropriate program guidelines

\subsection{The psychosocial services were not available}

The psychological services for IDUs had a positive impact to the therapy process, therapy adherence and solved the problems.

\subsection{The performance of health workers had not optimal in services}

The ratio of the number of health workers and patients was not balanced. The limited of health workers by rotation impact, workload and dysfunction of health workers in services, lack of supervision of the health department didn't lead to optimal health worker performance in providing assistance (the $\mathrm{MoH}$ Republic of Indonesia and World Health Organization 2011).

\subsection{External factors that influenced patient adherence}

Lack of patient adherence due to external factors caused IDUs dropped out form program. There were still many IDUs who injected with other than methadone. Feelings worried about IDUs was due to the operation of drug user that changed all the time (UNIKA ATMAJAYA 2015).

\section{Discussion}

Based on operational research conducted by the Center for HIV and AIDS research in 2015 , there was a need for cooperation between service providers and service beneficiaries in the therapeutic process. Methadone treatment is a long-term therapy, requiring patience. Service providers not only provided services to theirs patients but also psychosocial interventions. (UNIKA Atma Jaya 2015).

Psychosocial intervention is an approach that prioritizes the social and psychological problems carried by the patient that due to increasing the patient's ability to solve the problems. To carry out this intervention, it needs specialized skills training and specific criteria by the type of response (Setiyawati 2015). 
Knowledge of psychosocial intervention is one component in MMT that must-have service to provide optimal service to clients. However, based on research conducted in the field, it did not yet had psychosocial services. Therefore, it was necessary to develop an intervention by strengthen the capacity of health workers. The purpose of enhancing the ability of health workers was a retention improvement and patient compliance and to reduce the use of drugs other than methadone(UNIKA Atma Jaya 2015).

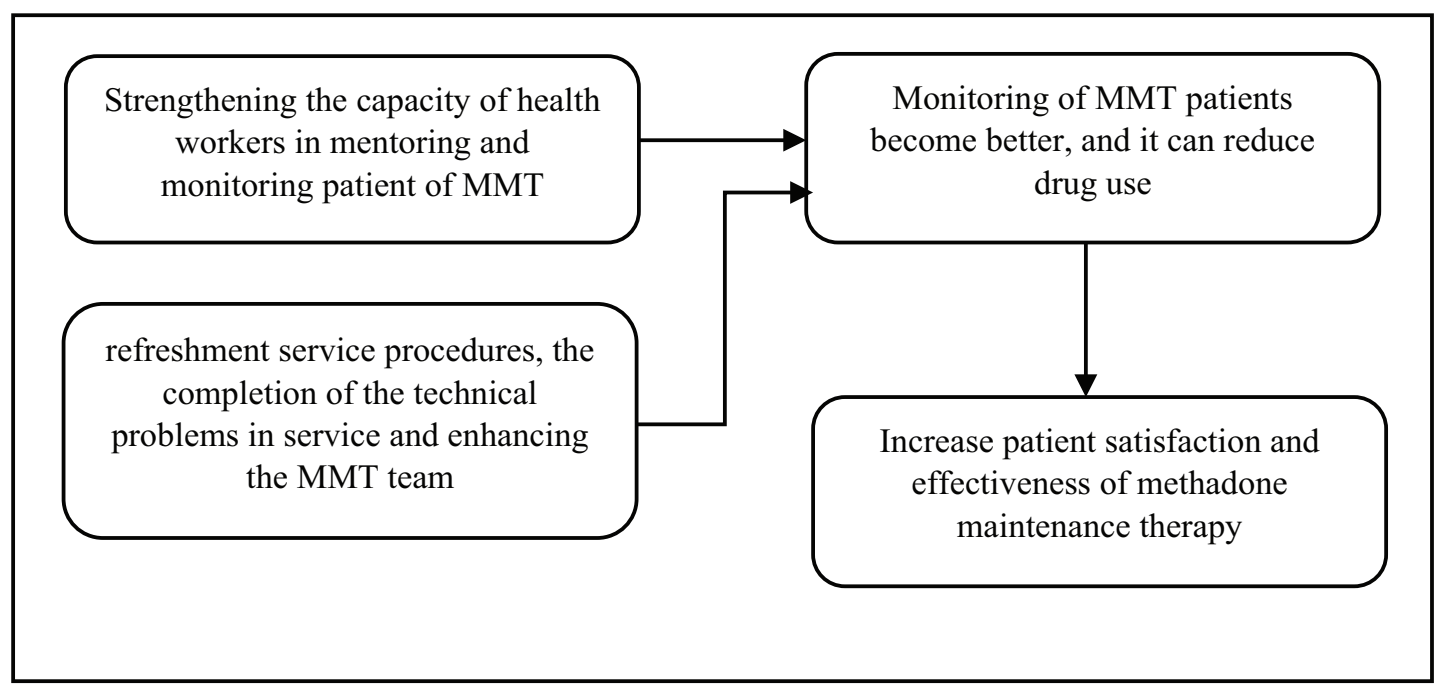

Figure 7: Overview Intervention in Capacity Building Health Workers according to the Center for Research on HIV \& AIDS UNIKA Atma Jaya (Source: HIV \& AIDS Research Center of UNIKA Atma Jaya (2015)).

The problem of adherence patients to therapy should be explored in depth between a service provider and client of treatment. Adherence seeks to empower patients by broadening the choices they can make, how they react to and cope with illness, and helping them to obtain information. In the process of therapy, the patient got involved in the rule-making process in accordance with their conditions(Myers and Midence 1998).

This therapy could fail if non-adherence patients, due to several things, like memory factors, information, were not aware about the rules they could make; the communication between the doctor to the patient was not good, making the confidence level of the patient low.

The external factors that could influence the patient adherence in MMTP could seen from the availability of methadone in health facilities, psychological changes of patient and information of operations against drug users by police (UNIKA Atma Jaya 2015).

\section{Conclusions}

Based on the study about injecting drug users and health workers in one of MMTP, it could be concluded: the first, most of the health worker in the service of MMTP already 
implemented the service according to the procedure. In this case, the government must continue to socialize MMTP service procedures. Second, it needed to develop psychosocial services to attract injecting drug users to survive during the therapy process, so that it could decrease the drop-out rate and the number of active patients. Third, it needed the capacity building of health workers, new information through education and training to all health workers.. The government, health agencies, and institutions should work together to socialize about MMTP services. Fourth, the government makes supervision of capacity for monitoring and evaluation to the service, so that the MMT service becomes better. Fifth, every unit needed a variety of service MMTP to avoid saturation of both patients and healthcare workers. However, the active treatment and good politics could reduce the social stigma due to drug dependence that methadone therapy could work well.

\section{Acknowledgments}

The author thanks the Foundation Karisma who has facilitated the process of interviews with injecting drug users and the drug Sub-Directorate of Ministry of Health that provide a source of ideas as material literature.

\section{References}

[1] Herman Joseph, Ph.D.; Sharon Stancliff, M.D; John Langford, Ph.D. 2000. "Methadone Maintenance Therapy: A Review of Historical and Clinical Issues." PubMed 1, 13-15.

[2] HIV \& AIDS Research Center of UNIKA Atma Jaya. 2015. Operation Research: Evaluation and Intervention Treatment of Methadone Maintenace Therapy (MMT). 2015: HIV \& AIDS Research Center of UNIKA Atmajaya.

[3] Ministry of the Health Republic of Indonesia and the World Health Organization. 2011. Opioid Substitution Therapy (OST) Review Implementation in Indonesia. Jakarta: Ministry Of Health.

[4] Ministry of the Health Republic of Indonesia: Directorate Control and Prevention of Mental Health. 2015. Methadone Maintenance Therapy in Indonesia. Jakarta.

[5] Ministry of the Health Republic of Indonesia: Directorate General of Disease Control and Environmental. 2011. IBBS 2011: Integrated Biological and Behavioural Survey. Jakarta.

[6] Ministry of the Health Republic of Indonesia: Directorate General of Disease Control and Environmental. 2013. IBBS in Risk Group. Jakarta. 
[7] Myers, Lynn B., and Kenny Midence. 1998. Adherence to Treatment in Medical Conditions. Amsterdam: Harwood Academic Publishers.

[8] Roz Azinur Che Lamin; Che Noriah Othman; Nursyuhadah Othman. 2013. "Behavior Study of Methadone Maintenance Therapy: Awareness Amongst Public in Malaysian Hospital." Science Direct 9-10.

[9] Setiyawati, Linda Susilaningtyas, Anik Nurcahyuni, Danang Sutawijaya. 2015. Buku Seri Bahaya Narkoba Jilid 5. Surakarta: PT. Tirta Asih Jaya.

[10] UNIKA Atma Jaya. 2015. Mau Sampai Kapan Saya Metadon?. Jakarta: Pusat Penelitian HIV \& AIDS Unika Atma Jaya. 